generally like to use them except for killing small game, as they often broke, and they have told me that their boomerangs were not 'strong enough' to kill a man. For fighting they have no throwing weapons--no throwing-sticks for their spears, but throw them by the hand, and only do so in extremity, for the spear is too valuable a weapon. It is only used as a pike; and they obtain their spears by barter from some tribe to the north. In ordinary fighting they use a weapon like a boomerang from 4 to 5 feet in length. It is held in both hands and blows are struck with the convex edge. They were not warded off when I saw it used, but the blows were struck indiscriminately -a sort of free fight. These weapons are made by themselves of boxwood.

"In throwing the boomerang I have seen it usually beld nearly parallel with the horizon. When thus thrown it would rise and return towards the thrower, but the blackfellows always told me that al though they could ensure its returning near them they could not tell exactly where it would come to. They could tell the direction but not the distance. If the boomerang strikes anything its course ceases.

"Some years ago the blackfellows living in the mountains just south of Blanchewater had no boomerangs and no spears. Their weapons were yamsticks and stones. They had no shields. Boomerangs, spears, and shields were acquired by them from the Blanchewater blacks, in return for which they bartered Wallaby rugs; at that time the Blanchewater and Deerie blacks had absolutely no clothing.

"This system of barter is said to have been instituted by a $\mathrm{Hil}$ blackfellow named Pompey, who, in 1856 , was concerned in the spearing of two men at Angepina. He escaped and went north to the Deerie blacks, having first stayed some time with the Blanchewater blacks, who understood both languages, being a border tribe. He took up to the Deerie blacks some flour, sugar, tobacco, and for some time settled at Kopparamanna. He endeavoured to raise a confederacy to drive the white settler out of the Flinders Range, and is said at that time to have instituted the system of barter.

"I knew this Pompey in 1857, when he sent another blackfellow, named Blanchewater Charley, to offer his services as 'nauto shepherd.' When Pompey then came in he told me much of the above concerning himself, which was also current ameng the tribes. He was a very shrewd fellow, and thus became a leader among them. He was afterwards shot for killing stationblacks. The national weapons of the Blanchewater blacks are stones. These are thrown of the size of the fist, and are perhaps thrown as far as a hundred yards, and with precision for forty yards; and in throwing, a rotatory motion is imparted to the stone. At about forty to fifty yards they can hit a smal mark, such as a bottle, almost without fail. In fighting at close quarters they ward off spear blows by means of a short stick held in the hand, and if possible, in cases where the spear has been thrown, clutching it in passing with the other. They do not use a shield for stopping spears, but against stones, which, as I have said, are the national weapons."

Although much of the above cannot be said to be strictly belonging to the "boomerang," I have preferred to give $\mathrm{Mr}$ James's statements in full as given to me.

Much that he says corroborates the statements I have made in the letter referred to.

It is much to be regretted that no one else than myself among your readers in Australia has recorded their observations on the "boomerang," in reply to your correspondent's request.

$$
\text { Bairnsdale, Gippsland, Victoria A. W. Howitr }
$$

\section{Longmynd Rocks}

Mr. H. B. Woobward, in his "Geology of England and Wales," p. 28, states that, near Shrewsbury, the Longmynd Rocks are overlaid conformably by the Lingula Flags. I should be glad to see the evidence upon which this conclusion is based So far as $I$ have examined the district, the facts do not sustain Mr. Woodward's view. Arenig fossils are found at the very head of the ravines which cut back nearly to the quartzite of the Stiper Stones. The beds under the quartzite are similar in lithological character to the Arenig shales above, and I have not heard of the lower shales yielding lingula flag fossils. At the base of the escarpment is the fault which separates the Stiper Stones rocks from the Longmynd beds. I believe the Stiper Stones beds are Arenig, in the absence of proof to the contrary. The quartzose band of the Stiper Stones may represent the arenaceous bed adopted by the Geological Survey as the base of the Arenig.

Wellington, Salop, January is
The Measurement of the Height of Clouds

IT has always been a matter of some interest to obtain measures of the height of clouds, independently of observations made from balloons or on mountains.

During last July and August I made a series of measures of cloud-altitudes--the first, I believe, of their kind-by photographing the clouds simultaneously from different stations.

The details of the process would occupy too much space to be inserted here, but I have reason to believe that the results obtained are not as much as three per cent. in error. The cirrus clouds which I measured varied in height from 22,000 to 25,000 feet ; massive cumuli from 6,000 to 7,000 feet. I did not get any good examples of cirro-cumulus or stratus. Rain-clouds appeared at all altitudes up to 4,000 feet. I hope to resume the measures at some future time.

Terling Place, Witham

\section{Mimetic Habit of Bats}

IN September, 1875, whilst paddling in a dorey (dug ou boat) through a narrow and dark creek leading from Belize River, Honduras, to Reid's lagoon, we disturbed a number of small bats which were clinging to the trunks and branches of the mangroves overhanging the water. These bats were about six inches in expanse and of a grey colour so exactly corresponding with that of the trees on which they settled as to be with diffculty distinguishable even at a distance of only a few feet. They invariably clung to the trunk or bough with wings expanded, and were never, so far as I noticed, suspended from the branches.

I saw the same species in Black Creek of the same river in February last year clinging to the trees in a similar manner, and conclude it is the natural position of the animal when at rest. I send this note as I do not recollect having anywhere seen this curious mimetic resemblance and peculiar habit ramarked upon. IOI, Grove Street, Liverpool, January 22 S. ARCHER

\section{THE SPONTANEOUS GENERATION QUESTION}

THE following paper on this subject was read at the Paris Academy oi Sciences on January $8^{3}:-$

The Academy has perhaps not forgotten that at the seidnce of July Io last, Dr. Bastian announced the discovery by him of the physico-chemical conditions necessary and sufficient for the spontaneous generation of certain varieties of microscopic objects of the genus Bacteria. The experiment which, according to Dr. Bastian, realises these conditions is very simple ; it consists in exactly neutralising by liquor potasse urine deprived of every organic germ and exposing the mixture to a temperature of fifty degrees. In those conditions certain varieties of bacteria promptly appeared.

Dr. Bastian has no doubt as to the bearing of his conclusions. To all who are attentive to medical movements it is evident that the debate relative to spontaneous generation has been removed into the domain of the etiology of contagious diseases.

I immediately repeated the experiment, and I proved, among other things, that it is sufficient to determine the saturation of the urine by solid potash instead of potash in aqueous solution (which does not modify whatever be the physico-chemical conditions to which it is subjected) for the mixture to remain perfectly sterile. I hence concluded that the interpretation given by Dr. Bastian to his experiment was totally inadmissible.

Dr. Bastian replied (Comptes Rendus, July $3 \mathrm{I}$ and August 2I) he did not at all dispute the legitimacy of my reasoning, but he affirmed that I reproduced his experiment badly and exceeded the exact point of neutralisation of the urine. Such is, according to him, the cause of the sterility of the liquid in my hands.

The question is then limited to the point: Have I done any thing else but replace the liquor potasse by melted potash, and specially, have I exceeded the point of saturation of the urine, and is there anything amiss in so doing?

I have examined the debate reduced to these terms, along with M. Joubert, with all the attention of which we are both of us capable, and we are able to declare to the Academy, on the basis of new experiments, that the exact neutralisation of the urine by solid potash, which we had melted, left the urine sterile. We add, although that may not be indispensable, that there is no obstacle to the fertilisation of urine, in the experi-

$x$ Continued from p. 303

2 Note on the Alteration of Urine in reference to Recent Communications of Dr. Bastian, by MM. Pasteur and Joubert. 